\title{
図書紹介
}

\author{
金原 粲著「真空・薄膜徒然草」* \\ 中 山 勝 矢 $^{* 1}$
}

\section{Book Review of "Gleanings from My Research on Vacuum and Thin Films" [in Japanese] written by Akira KINBARA}

\section{Katsuya NAKAYAMA*1}

(Received March 12, 2013, Accepted March 26, 2013)

これは, 著者が半世紀以上にわたり携わってきた真空と薄 膜に関する研究の随想集である（図 1)。自分の研究史を書 く気でいたが，思い直して随想集にしたとある.

気軽な読み物かと思って手に取ると, 専門の教科書の陰に 隠れた意味を考えさせ, 数々の問題に気付かせてくれる素晴 らしい本なのである.いわば講義の際になされる余談の類い が集められていて, 滅多に聞けない話が聞ける.

著者の経歴は, 東京大学大学院を振り出しに, 母校の教授 を定年まで勤め, 金沢工業大学に移っただけでなく，その間 に応用物理学会の会長も務めたのだから輝かしい。

その長い過去の経歴から面白かったこと, 疑問に思ったこ と, そして未解決なことを, 気の向くままに率直に述べたか ら「徒然草」なのだあるが，それは性格のなせる発言であ って, 内容は鋭く，とてもそんな生易しいものではない.

功成り, い屯やご隐居様然と構える傘寿の大先輩から若手 の後輩が「分かっているかい」と突っ込まれた気分になる貴 重な本である. 组上に載せられているのは真空と薄膜の自然 哲学的思惟で, 日ごろ素通りしている部分なのだ.

実験の道具に関する話もたくさん出てくる，研究室はみす ぼらしく, 研究費の乏しい時代に目的達成のため何を考え, どんな知恵を絞ったかという研究の裏話は, 懐かしくもある が，価值があり，文化遺産に通じるものを感じる。

今は常識として扱われている概念, たとえば薄膜形成の初 期過程に関して, 誰がいつ, どんな実験結果をべースに島構 造モデルを提言したのかなど, 原典まで遡って調べているの には頭が下がる。

まえがきにあるように, 本誌（正式名：Journal of the Vacuum Society of Japan) の随想欄に20回にわたって連載 されていたので, 既に目を通している読者も多いと思うが,

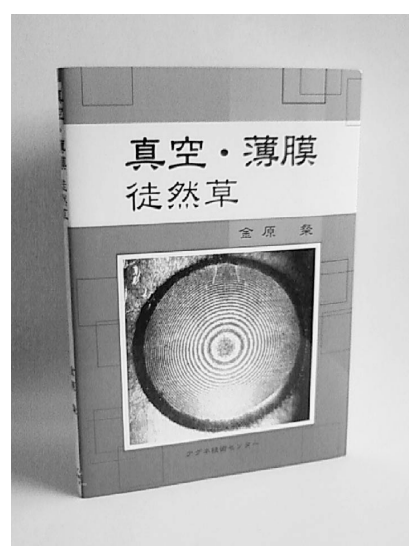

図 1 「真空·薄膜徒然草」表紙.

合本したものを通読すると, 改めて内容の深さに驚く.

付け加えていえば, 大学時代の教授, 留学先での指導者, 研究室の同輩, 後輩, 論文の共著者なぞ, 長い人生でかかわ った人が多く出てくる. そのなかには知人も多くいて, 興味 が湧く.いずれも仕事に関係して触れているに過ぎないのだ が，人柄が的確に描かれているのに驚く.

もう一つ興味深かったのは, 留学先での生活のことだ.そ こで経験した生活レベルの追憶は自分の記憶とほぼ同じで, これなども貴重な記録になるかもしれない.

こうした公式の記録に記載されないような様々な苦労話や 失敗談は, 捨ててしまうのは余りにも惜しい. 平均寿命が伸 びたのだから, 現役を退き, 余㗇を手にした人は, 想いを込 めて自分史を残すことが，未来に対するささやかな貢献にな るのではないだろうか。読むことを打勧めする.

\footnotetext{
*侏アグネ技術センター, 東京, 2013 [in Japanese]

*1 広島工業大学名誉教授
} 